\title{
FACTORS AFFECTING COLLATERALIZED BORROWING BY SMES: EVIDENCE FROM EMERGING MARKETS
}

\section{Aysa Ipek Erdogan ${ }^{a}$}

\begin{abstract}
This study aims to enhance the empirical evidence on the determinants of collateralized borrowing by small and medium-sized enterprises (SMEs) by presenting new empirical evidence on emerging market countries. Using the data from World Bank Enterprise Surveys from nine emerging markets, we find that older SMEs are less likely to provide collateral for bank loans. The results also reveal that loans received by firms whose top managers are more experienced in the industry and firms with a higher percentage of material inputs and services purchased on account are less likely to be secured. SMEs in the manufacturing industry are more likely to provide collateral for bank loans than service industry firms. The likelihood that the loan is secured is higher for firms with larger loan sizes. Furthermore, our results indicate that the probability of pledging collateral is higher for SMEs that operate in countries with higher borrower-bank proximity.
\end{abstract}

Keywords: Collateral, SMEs, emerging markets, SME financing, bank loans, banks JEL Classification: G21, G30, G32, O16

\section{Introduction}

SMEs play a critical role in employment creation, productivity growth and innovation in all economies in the world. These firms are highly dependent on bank financing for survival and growth. However, financial literature reveals that SMEs encounter difficulties in their access to bank loans because of higher risks that result from higher information asymmetry (e.g., Berger and Udell, 2002; Berger and Udell, 2006). Several studies show that inadequate access to bank financing is seen as the basic obstacle that SMEs encounter (e.g., CarboValverde et al., 2016; Beck et al., 2008). Lending to SMEs is considered to be of high risk by banks because of their opacity and heterogeneity (Dvouletý, 2017). Having a short history, a small scale, inadequate financial reporting and a limited credit history adds to the opacity

a Bogazici University, Department of Tourism Administration, Bebek, Istanbul, Turkey

Email: aysa.erdogan@boun.edu.tr 
of SMEs (Scott, 2006). These firms also face difficulty in providing collateral for bank loans because inability to access bank financing causes slow building-up of assets (Wasiuzzaman et al., 2019). Governments use credit guarantee schemes to compensate for the inability of SMEs to provide adequate collateral. Although several studies in the literature provide evidence that credit guarantee schemes ease access to bank loans (e.g., Cowling, 2010; Zecchini and Ventura; 2009), there are also studies that argue that the schemes can crowd out bank financing by providing loans to SMEs that would have obtained bank financing without the guarantee (Rocha et al., 2011). On the other hand, Dvouletý et al. (2019) argue that credit guarantee schemes create a risk of moral hazard and loss of public funds because SMEs may take large loans that exceed their needs or they may finance risky investments that could not be financed by traditional bank loans through these schemes.

Emerging markets are economies that have low to middle per capita income and that progress towards becoming developed economies with industrialization, high growth and integration with global product and capital markets (Bernanke, 2011). These economies account for more than one-quarter of global output and more than half of the increase in global output in the period 2010-2015 (Huidrom et al., 2017). SMEs play a crucial role in emerging market economies as well. On average, formal SMEs account for $60 \%$ of total employment and generate $50 \%$ of national income (GDP) in emerging markets (World Bank, 2018).

Challenges faced when obtaining bank loans are more acute for emerging market SMEs because of their inclination to remain in the informal economy to evade regulation and taxation (OECD, 2006). Moreover, the information asymmetry problem is more severe in emerging markets because of inadequate monitoring by institutions, high ownership concentration and lack of strong financial systems (Chung et al., 2017). IFC (2017) shows that $60 \%$ of SMEs in emerging and developing markets are not served or underserved by the banking sector.

Several studies in the literature argue that collateral may act as a signalling or incentive device if information asymmetry in the loan markets causes adverse selection (e.g., Bester et al., 1985) and moral hazard (e.g., Boot et al., 1991). If the borrower's quality is unknown, collateral may be used as a signalling instrument against the adverse selection problem because firms with lower risk can try to secure a low interest rate by disclosing themselves with the provision of an amount of collateral that would not be acceptable for firms with a high risk of default. Moreover, because collateral increases the penalty for default, it persuades firms to choose projects with lower risk. Consequently, the moral hazard problem is alleviated because the bank's and the firm's interests are compulsorily aligned.

Since collateral is a contractual instrument that affects SMEs' access to bank loans, analysing the firm-specific and loan-specific variables that affect collateralized 
borrowing is an important contribution to the SME financing literature. Because of higher information asymmetry and weak enforcement procedures, collateral is a mechanism that assumes a more important role in emerging markets. This study aims to add to the literature by analysing the determinants of collateralized borrowing for emerging market economies and presenting new evidence on the effects of previously unexplored factors on the incidence of collateral. To our knowledge, this work is one of a scant number of studies that analyse the determinants of collateralized borrowing in emerging market economies. The paper also provides the first evidence on whether firm growth rate, firm's percentage of credit sales to total sales and the country's financial development level affect the likelihood of pledging collateral. Moreover, it is the first study to test empirically whether there is a difference between firms that operate in the manufacturing industry and firms in the service industry in terms of their likelihood of providing collateral for bank loans. The paper also gives evidence that does not support the previously proposed negative relationship between firm size and the incidence of collateral. One other contribution of the study is that unlike the previous studies that analyse the determinants of collateralized borrowing, it runs additive models where the interaction effects between several independent variables are tested.

The dataset for the study is obtained from World Bank Enterprise Surveys (WBES) conducted in 9 emerging markets in the period 2010-2017. Our sample is composed of SMEs that operate in five of the seven largest emerging markets, which are China, India, Mexico, Russia and Turkey (Huidrom et al., 2017), and additionally Chile, Colombia, Peru and the Philippines.

The paper is organized as follows: Section 2 reviews the related literature, Section 3 describes the research methodology, and Section 4 depicts the sample. Empirical findings are reported in Section 5 and Section 6 concludes the paper.

\section{Determinants of Collateralized Borrowing}

We draw on prior literature examining the factors that have a relationship with collateralized borrowing to propose the firm-level, loan-level, and country-level determinants that can affect collateral requirements.

\subsection{Firm-level and loan-level determinants of collateralized borrowing}

\subsubsection{Firm age}

Harhoff and Körting (1998) suggest that because firm age is a signal of observable reputation, it should have a negative relationship with the likelihood of the provision 
of collateral. Moreover, Rahman et al. (2017) indicate that the likelihood of pledging collateral is expected to be lower for older firms because they can present past business information in their loan applications. Supporting these arguments, several studies in the literature provide evidence that firms that pledge collateral are more likely to be younger firms (e.g., Berger and Udell, 1995; Chakraborty and Hu, 2006; Harhoff and Körting, 1998). In their emerging market study, Menkhoff et al. (2006) show that banks use collateral to decrease the larger credit risks of young firms, and the likelihood of collateralization decreases with firm age. Thus, we test the following hypothesis:

Hypothesis 1 (H1): Firm age is negatively associated with the likelihood of pledging collateral for bank loans.

\subsubsection{Firm size}

Knyazeva and Knyazeva (2012) argue that lower information transparency of larger firms may decrease their likelihood of pledging collateral. Moreover, Steijvers et al. (2010) indicate that because size can be considered a proxy for prior success, banks may require lower collateral from larger firms. A number of studies in the empirical literature show that larger firms are less likely to provide collateral to obtain bank loans in developed countries (e.g., Harhoff and Körting, 1998; Knyazeva and Knyazeva, 2012) and in emerging markets (e.g., Hanedar et al., 2014b; Menkhoff et al., 2006). Thus, we propose the following hypothesis:

Hypothesis 2 (H2): Firm size is negatively associated with the likelihood of pledging collateral for bank loans.

\subsubsection{Firm growth rate}

Binks and Ennew (1996) suggest that high-growth firms encounter a different form of the information asymmetry problem because gathering and handling information about them is difficult for banks due to their rapid rate of change. Moreover, Freel et al. (2012) argue that high recent growth rates of a firm may be interpreted by banks as a sign of cash constraints and problems in the provision of collateral. Brown and Lee (2019) indicate that high-growth firms prefer to make risky investments such as acquisitions and R\&D instead of using available funds to acquire fixed assets that have a certain resale value. Since firm growth is argued to increase information asymmetry and the risk of a firm, we hypothesize as follows:

Hypothesis 3 (H3): Firm growth rate is positively associated with the likelihood of pledging collateral for bank loans. 


\subsubsection{Ownership concentration}

Hanedar et al. (2014a) suggest that because the enforcement process is less effective in firms that are owned by more than one person, the likelihood of the procurement of collateral is higher. The authors provide evidence that sole-proprietorship SMEs have a lower likelihood of providing collateral than other firms in their study of developing markets. On the other hand, Rahman et al. (2017) provide evidence that SMEs with more concentrated ownership have a higher likelihood of providing collateral. The authors argue that this finding may be the result of the tendency of firms with concentrated ownership to be involved in risk-shifting behaviour. Since the empirical evidence is conflicting in nature, we formulate the following nondirectional hypothesis:

Hypothesis 4 (H4): Ownership concentration is associated with the likelihood of pledging collateral for bank loans.

\subsubsection{Percentage of credit sales to total sales}

Several studies in the literature argue that the liquidity status of a firm negatively affects the risk of financial distress (e.g., Brealey et al., 2020; Christopoulos et al., 2018; Zikovic, 2018). The "observed risk" hypothesis suggests that when banks can observe the borrower's risk, they are more likely to require collateral from high-risk borrowers to be able to cover the costs if default occurs (Berger and Udell, 1990). Since banks can observe the percentage of credit sales to total sales (Brealey et al., 2020), we propose the following hypothesis:

Hypothesis 5 (H5): Percentage of credit sales to total sales is positively associated with the likelihood of pledging collateral for bank loans.

\subsubsection{Experience of top manager}

Leeth and Scott (1989) point out that having inexperienced managers increases the likelihood of default, and the probability of non-payment positively affects the incidence of collateral. In a similar vein, Duarte et al. (2017) state that firms with more experienced CEOs have more established relationships with banks and this factor may decrease the probability of the provision of collateral to obtain bank loans. The authors provide evidence that the experience of the top manager of an SME negatively affects the likelihood that the bank loan is secured. Thus, we test the following hypothesis:

Hypothesis 6 (H6): The number of years of experience of the top manager in the industry is negatively associated with the likelihood of pledging collateral for bank loans. 


\subsubsection{Having an internationally recognized quality certification}

Hanedar et al. (2014a) argue that having an internationally recognized quality certification (e.g., ISO 9000, 9002, or 14000) is a signal of higher borrower quality. Moreover, Minard (2016) suggests that because obtaining quality certifications is costly, having such a certification may reduce information asymmetry and signal better borrower quality. Duarte et al. (2017) provide evidence that firms that hold an internationally recognized quality certification have a lower likelihood of providing collateral to obtain bank loans. Since holding such a certification is a reputational indicator for SMEs, we test the following hypothesis:

Hypothesis 7 (H7): Firms that have an internationally recognized quality certification are less likely to pledge collateral for loans than firms that do not have such a certification.

\subsubsection{Percentage of material inputs and services purchased on account}

Gama and Van Auken (2015) argue that when suppliers extend trade credit to a firm, they send a reassuring signal to banks about the firm's credit quality. Moreover, Duarte et al. (2017) suggest that firms can increase their likelihood of obtaining bank loans without collateral by signalling their credit quality with a high proportion of material inputs and services paid on account. The authors provide evidence that the percentage of material inputs and services purchased on account has a negative relationship with collateral use. Thus, we test the following hypothesis:

Hypothesis 8 (H8): Percentage of material inputs and services purchased on account is negatively associated with the likelihood of pledging collateral for bank loans.

\subsubsection{Industry}

Rahman et al. (2017) argue that firms that have a high level of tangible assets are more information-transparent than firms with a low level of tangible assets. Moreover, tangible assets can be liquidated by banks to recover loans in the case of default. Knyazeva and Knyazeva (2012) provide evidence that asset tangibility has a negative relationship with loan spreads and suggest that the tangibility of assets reduces the extent of the information asymmetry problem and financial distress costs. Since firms in the manufacturing industry have higher asset tangibility than those in the service industry, we propose the following hypothesis:

Hypothesis 9 (H9): Firms that operate in the manufacturing industry are less likely to pledge collateral for loans than firms that operate in the service industry. 


\subsubsection{Loan size}

Jimenez et al. (2006) argue that banks require less collateral for larger loans because the payoff from large loans is higher in favourable economic conditions. Supporting this argument, Boot et al. (1991) and Jimenez et al. (2006) show that the quantity of collateral required decreases with loan size. Godlewski and Weill (2011) also provide evidence that loan size has a negative relationship with the likelihood of the provision of collateral. On the other hand, Menkhoff et al. (2012) argue that smaller loans have a lower probability of being collateralized because they have a lower chance of creating an impetus for default. Supporting this, Hanedar et al. (2014b) find a positive relationship between the size of the loan and collateral use for SME loans. Since the theoretical arguments and prior empirical studies are contradictory, we test the following nondirectional hypothesis:

Hypothesis 10 (H10): Loan size is associated with the likelihood of pledging collateral for loans.

\subsection{Country-level determinants of collateralized borrowing}

\subsubsection{Borrower-bank proximity}

Rahman et al. (2017) argue that a short distance between the borrower and the lender eases access to soft information and reduces information asymmetry. In the same vein, Hainz et al. (2013) suggest that if the distance of the bank to its customer is short, the adverse selection problem can be solved by screening rather than requiring collateral. Moreover, Duarte et al. (2017) provide evidence that the proximity between the borrower and the bank has a negative relationship with the incidence of collateral. Thus, we test the following hypothesis:

Hypothesis 11 (H11): Proximity between the borrower and the bank is negatively associated with the likelihood of pledging collateral for loans.

\subsubsection{Financial development}

Beck et al. (2006) find that firms that operate in countries with a higher level of financial development have better access to finance. In a related study, Godlewski and Weill (2011) suggest that since the financial development of a country positively affects the risk analysis skills of bank employees, information asymmetries and the likelihood of collateralization are lower in countries with higher levels of financial development. The authors provide evidence that financial intermediary development has a negative relationship with the incidence of collateral. Thus, we propose the following hypothesis: 
Hypothesis 12 (H12): Financial development in a country is negatively associated with the likelihood of pledging collateral for loans.

\section{Empirical Model}

This paper uses logistic regression analysis to investigate the effects of the independent variables on collateral use. The dummy variable Collateral is the dependent variable used in the model; it is equal to 1 if the firm has provided collateral for its most recent line of credit and 0 otherwise. Logistic regression transforms the binary dependent variable into the natural logarithm of the odds of the outcome. In our case, the dependent variable is transformed into the natural logarithm of the odds of the procurement of collateral for bank loans. Our logistic regression model that analyses the determinants of collateral use is as follows:

$\operatorname{Ln}\left(\mathrm{P}_{\text {Collateral }, \text { ky }} / 1-\mathrm{P}_{\text {Collateral }, i k y}\right)=\beta_{0}+\beta_{1}$ Firm Age $_{i k y}+\beta_{2}$ Firm Age $_{i k y}{ }^{2}+\beta_{3}$ Firm Size $_{i k y}+$

$+\beta_{4}$ Growth Rate $_{i k y}+\beta_{5}$ Ownership Concentration $i k y+\beta_{6}$ Credit Sales $_{i k y}+$

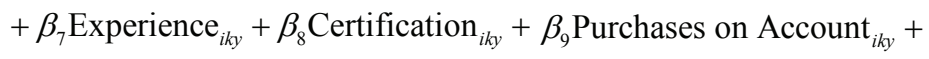

$+\beta_{10}$ Industry $_{i k y}+\beta_{11}$ LoanSize $_{i k y}+\beta_{12}$ Country $_{k}+\beta_{13}$ Year $_{y}+\varepsilon_{i k y}$.

$P_{i k y}$ is the probability of providing collateral for the most recent line of loan for the participant $i$ operating in the country $k$ in the year $y$, and $1-P_{i}$ represents the probability of not providing collateral for the most recent line of loan for the participant $i$ operating in the country $k$ in the year $y$.

Among the independent variables, Firm Size stands for the natural logarithm of the number of full-time employees. Firm Age represents the natural logarithm of firm age. To determine whether the relationship between firm age and collateral use is nonlinear, a squared firm age term is included in the model. Growth Rate is the percentage change in the number of employees in the last three years. Ownership Concentration is the percentage of the firm held by the largest owner (Brealey et al., 2020). Credit Sales represents the percentage of credit sales to total sales (Brealey et al., 2020). Experience stands for the natural logarithm of the years of experience of the top manager in the industry. Certification is the dummy variable that shows whether the SME has an internationally recognized quality certification. The dummy variable is 1 if the firm has such a certification; otherwise, it equals 0. Purchases on Account represents the percentage of the value of total annual purchases of material inputs or services paid after delivery (Brealey et al., 2020; Brigham et al., 2020). Industry represents industry dummy variables for the manufacturing industry and service industry. The service industry dummy variable 
is excluded from the logistic regression analysis. Loan Size stands for the natural logarithm of the total value of the loan, which is expressed in thousands of dollars. Country and Year are dummy variables for the country and the year in which the loan is approved. Clustered error terms are allowed in the analysis because error terms can be correlated for SMEs within countries.

In the second step, we run the model with the country-level variables instead of the country dummies. The new model is as follows:

$$
\begin{aligned}
& \text { Ln }\left(\mathrm{P}_{\text {Collateral } i k y} / 1-\mathrm{P}_{\text {Collateral }, i k y}\right)=\beta_{0}+\beta_{1} \text { Firm Age }_{i k y}+\beta_{2} \text { Firm Age }_{i k y}{ }^{2}+\beta_{3} \text { Firm Size }_{i k y}+ \\
& +\beta_{4} \text { Growth Rate }_{i k y}+\beta_{5} \text { Ownership Concentration }_{i k y}+\beta_{6} \text { Credit Sales }_{i k y}+ \\
& +\beta_{7} \text { Experience }_{i k y}+\beta_{8} \text { Certification }_{i k y}+\beta_{9} \text { Purchases on Account }_{i k y}+\beta_{10} \text { Industry }_{i k y}+ \\
& +\beta_{11} \text { LoanSize }_{i k y}+\beta_{12} \text { Borrower-Bank Proximity }_{k}+\beta_{13} \text { Financial Development }_{k}+ \\
& +\beta_{14} \text { Year }_{y}+\varepsilon_{i k y} .
\end{aligned}
$$

Borrower-Bank Proximity represents the closeness of the lender and the borrower, and the variable is proxied with the natural logarithm of the number of branches of commercial banks per 100,000 adults. Financial Development stands for the financial development level of the country and is measured using the ratio of the volume of credit to the private sector to GDP. The country-level variables come from World Bank Open Data and are averaged over a period of three years, including the survey year and the two years prior to the survey year.

The definitions of the variables used in the logistic regression model are given in Table 1.

\section{Data}

We compose a cross-country sample that consists of emerging market economies for which WBES data are available for the period 2010-2017. The emerging market economies we select for our sample are 9 economies that are included in the MSCI Emerging Markets Index. Our sample is composed of 1,881 SMEs that had secured a bank loan. We define SMEs as firms that employ between 10 and 250 full-time employees. 
Table 1: Definition of variables used in the study

\section{Dependent variable}

\section{Collateral}

The dummy variable takes the value 1 if the firm has provided collatera for its most recent line of credit and 0 otherwise.

\section{Independent variables}

\section{Firm characteristics}

\begin{tabular}{|c|c|}
\hline Firm Age & Number of years the firm has been operating \\
\hline Firm Age Squared & Number of years the firm has been operating squared \\
\hline Firm Size & Number of full-time employees \\
\hline Growth Rate & Percentage change in the number of employees in the last three years \\
\hline Ownership Concentration & Percentage of the firm held by the largest owner \\
\hline Credit Sales & Percentage of credit sales to total sales \\
\hline Experience & Number of years of experience of the top manager in the industry \\
\hline Certification & $\begin{array}{l}\text { Dummy variable for whether the firm has an internationally recognized } \\
\text { quality certification. The dummy variable is } 1 \text { if the firm has such } \\
\text { a certification; otherwise, it equals } 0 .\end{array}$ \\
\hline Purchases on Account & $\begin{array}{l}\text { Percentage of the value of total annual purchases of material inputs } \\
\text { or services paid after delivery }\end{array}$ \\
\hline Industry & $\begin{array}{l}\text { Dummy variable showing whether the firm is in the manufacturing } \\
\text { or service industry. It equals } 1 \text { if the firm is in the manufacturing industry; } \\
\text { it equals } 0 \text { if it is in the service industry. }\end{array}$ \\
\hline
\end{tabular}

Loan characteristic variable

\begin{tabular}{l|l}
\hline Loan size & Total value of the loan in thousands of dollars \\
\hline \begin{tabular}{l} 
Country characteristics \\
\hline Borrower-Bank Proximity
\end{tabular} & Number of branches of commercial banks per 100,000 adults \\
\hline Financial Development & Ratio of the volume of credit to private sector to GDP \\
\hline
\end{tabular}

Source: Author

Among the firms in the sample, 1,068 are small enterprises (10-50 employees) and 813 are medium-sized enterprises (51-250 employees). The number of loans that are approved for the pooled sample is presented in Table 2 . 
Table 2: Distribution of sample of loans that are approved for the pooled sample

\begin{tabular}{c|c|c|c|c|c|c|c}
\hline \multicolumn{7}{c}{ Year the loan is approved } \\
\hline $\mathbf{2 0 1 0}$ & $\mathbf{2 0 1 1}$ & $\mathbf{2 0 1 2}$ & $\mathbf{2 0 1 3}$ & $\mathbf{2 0 1 4}$ & $\mathbf{2 0 1 5}$ & $\mathbf{2 0 1 6}$ & $\mathbf{2 0 1 7}$ \\
\hline 251 & 406 & 129 & 425 & 51 & 22 & 261 & 336 \\
\hline
\end{tabular}

Source: Own calculations

The distribution of the loans among countries is presented in Table 3.

Table 3: Country distribution of sample of firms that received a bank loan

\begin{tabular}{l|c}
\hline Country & \\
\hline Chile & 179 \\
\hline China & 214 \\
\hline Colombia & 324 \\
\hline India & 352 \\
\hline Mexico & 97 \\
\hline Peru & 270 \\
\hline Philippines & 73 \\
\hline Russia & 241 \\
\hline Turkey & 131 \\
\hline
\end{tabular}

Source: Own calculations

Table 4 gives the descriptive statistics for the variables used in the logistic regression models.

\section{Empirical Findings}

Table 5 gives the results of the binomial logistic regressions. A VIF value higher than 10 indicates there is no problem of high degree of multicollinearity in the dataset (Hair et al., 2018). Since our independent variables, the squared term of age and the interaction terms do not have a VIF value above 10, we can say that we do not encounter the problem of multicollinearity. Low bivariate correlations also indicate that the assumption of no multicollinearity is not violated (the correlation matrix is not reported here, but it is available from the author upon request).

The first four columns show the results of models where country dummies are included in the models. The first column gives the result of Model 1. In this model, the negative coefficient of Firm Age, which is statistically significant $(p<0.05)$, shows 
that older firms have a lower probability of providing collateral for bank loans. This result supports H1 and is consistent with the argument of Harhoff and Körting (1998) that firm age is considered a signal of observable reputation by banks. The finding also provides support for the finding of the emerging market study by Menkhoff et al. (2006) that banks require collateral to mitigate the higher credit risks of young firms. In the model, firm age squared has a statistically insignificant coefficient. This finding shows that there is no nonlinear relationship between firm age and collateral use.

Table 4: Descriptive statistics for pooled sample of firms that received a bank loan

\begin{tabular}{|c|c|c|c|c|c|c|c|c|c|}
\hline & 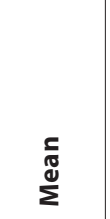 & 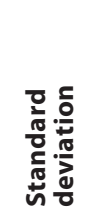 & 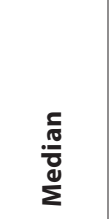 & 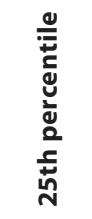 & 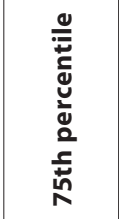 & 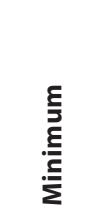 & $\begin{array}{l}\underline{\xi} \\
\frac{E}{x} \\
\frac{\pi}{\Sigma}\end{array}$ & 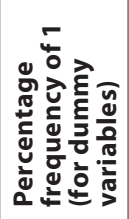 & 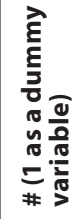 \\
\hline Collateral & - & - & - & - & - & - & - & 0.63 & 1,185 \\
\hline Firm Age & 20.54 & 15.72 & 16.00 & 10.00 & 26.00 & 1.00 & 162.00 & - & - \\
\hline Firm Size & 65.70 & 59.02 & 41.00 & 20.00 & 95.00 & 10.00 & 250.00 & - & - \\
\hline Firm Growth & 0.19 & 0.47 & 0.08 & 0.00 & 0.29 & -0.88 & 3.50 & - & - \\
\hline $\begin{array}{l}\text { Ownership } \\
\text { Concentration }\end{array}$ & 68.47 & 26.95 & 63.00 & 50.00 & 100.00 & 1.00 & 100.00 & - & - \\
\hline Credit Sales & 60.16 & 35.34 & 70.00 & 30.00 & 95.00 & 0.00 & 100.00 & - & - \\
\hline Experience & 20.98 & 10.82 & 20.00 & 12.00 & 30.00 & 1.00 & 53.00 & - & - \\
\hline Certification & - & - & - & - & - & - & - & 0.34 & 645 \\
\hline $\begin{array}{l}\text { Purchases } \\
\text { on Account }\end{array}$ & 58.30 & 33.91 & 60.00 & 30.00 & 90.00 & 0.00 & 100.00 & - & - \\
\hline Manufacturing & - & - & - & - & - & - & - & 0.69 & 1,291 \\
\hline Services & - & - & - & - & - & - & - & 0.31 & 590 \\
\hline Loan Size & 387,384 & 710,480 & 118,833 & 44,773 & 390,371 & 901 & $4,900,000$ & - & - \\
\hline $\begin{array}{l}\text { Borrower-Bank } \\
\text { Proximity }\end{array}$ & 15.41 & 8.53 & 13.74 & 8.26 & 17.30 & 7.69 & 36.66 & - & - \\
\hline $\begin{array}{l}\text { Financial } \\
\text { Development }\end{array}$ & 0.60 & 0.29 & 0.49 & 0.43 & 0.52 & 0.22 & 1.26 & - & - \\
\hline
\end{tabular}

Source: Own calculations 
Table 5: Logistic regression results

\begin{tabular}{|c|c|c|c|c|c|c|c|c|c|}
\hline \multicolumn{10}{|c|}{ Dependent variable: Collateral } \\
\hline $\begin{array}{l}\text { Independent } \\
\text { variables }\end{array}$ & & [1] & [2] & [3] & [4] & [5] & [6] & [7] & [8] \\
\hline \multirow{4}{*}{ Firm Age } & B & $-0.010^{* *}$ & $-0.016^{* *}$ & -0.010 & -0.010 & -0.009 & -0.014 & -0.009 & -0.009 \\
\hline & $\operatorname{Exp}(B)$ & 0.990 & 0.984 & 0.990 & 0.990 & 0.991 & 0.986 & 0.991 & 0.991 \\
\hline & Wald & $(4.079)$ & $(4.136)$ & $(4.060)$ & $(4.089)$ & $(2.937)$ & $(2.808)$ & $(2.883)$ & $(2.960)$ \\
\hline & VIF & 2.532 & 5.669 & 2.534 & 2.535 & 2.646 & 5.861 & 2.651 & 2.648 \\
\hline \multirow{4}{*}{ Firm Age ${ }^{2}$} & B & 0.00005 & 0.00005 & 0.00005 & 0.00005 & 0.00003 & 0.00003 & 0.00003 & 0.00003 \\
\hline & $\operatorname{Exp}(B)$ & 1.000 & 1.000 & 1.000 & 1.000 & 1.000 & 1.000 & 1.000 & 1.000 \\
\hline & Wald & $(0.294)$ & $(0.281)$ & $(0.291)$ & $(0.298)$ & $(0.118)$ & $(0.114)$ & $(0.112)$ & $(0.124)$ \\
\hline & VIF & 2.123 & 2.123 & 2.123 & 2.127 & 2.168 & 2.169 & 2.171 & 2.172 \\
\hline \multirow{4}{*}{ Firm Size } & B & 0.001 & 0.001 & 0.001 & 0.001 & 0.001 & 0.001 & 0.001 & 0.001 \\
\hline & $\operatorname{Exp}(B)$ & 1.001 & 1.001 & 1.001 & 1.001 & 1.001 & 1.001 & 1.001 & 1.001 \\
\hline & Wald & (2.121) & $(2.246)$ & (2.110) & (2.124) & $(2.112)$ & (2.211) & (2.089) & (2.132) \\
\hline & VIF & 1.255 & 1.257 & 1.255 & 1.256 & 1.256 & 1.258 & 1.256 & 1.257 \\
\hline \multirow{4}{*}{ Firm Growth } & B & -0.094 & -0.100 & -0.094 & -0.094 & -0.108 & -0.113 & -0.109 & -0.109 \\
\hline & $\operatorname{Exp}(B)$ & 0.911 & 0.905 & 0.910 & 0.911 & 0.898 & 0.893 & 0.897 & 0.897 \\
\hline & Wald & $(0.759)$ & $(0.865)$ & $(0.765)$ & $(0.762)$ & $(0.990)$ & $(1.075)$ & $(1.006)$ & (0.999) \\
\hline & VIF & 1.074 & 1.077 & 1.074 & 1.074 & 1.078 & 1.080 & 1.078 & 1.078 \\
\hline \multirow{4}{*}{$\begin{array}{l}\text { Ownership } \\
\text { Concentra- } \\
\text { tion }\end{array}$} & B & -0.042 & -0.041 & -0.041 & -0.042 & -0.036 & -0.036 & -0.035 & -0.037 \\
\hline & $\operatorname{Exp}(B)$ & 0.959 & 0.959 & 0.960 & 0.959 & 0.964 & 0.965 & 0.966 & 0.964 \\
\hline & Wald & $(0.052)$ & $(0.050)$ & $(0.050)$ & $(0.052)$ & $(0.038)$ & $(0.037)$ & $(0.035)$ & (0.039) \\
\hline & VIF & 1.035 & 1.035 & 1.036 & 1.035 & 1.042 & 1.042 & 1.043 & 1.042 \\
\hline \multirow{4}{*}{ Credit Sales } & B & -0.249 & -0.251 & -0.248 & -0.249 & -0.267 & -0.267 & -0.264 & -0.267 \\
\hline & $\operatorname{Exp}(B)$ & 0.779 & 0.778 & 0.780 & 0.779 & 0.766 & 0.765 & 0.768 & 0.766 \\
\hline & Wald & $(2.363)$ & (2.394) & $(2.316)$ & (2.363) & $(2.706)$ & $(2.720)$ & $(2.622)$ & (2.708) \\
\hline & VIF & 1.327 & 1.327 & 1.336 & 1.327 & 1.331 & 1.331 & 1.339 & 1.331 \\
\hline \multirow{4}{*}{ Experience } & B & $-0.016^{* * *}$ & $-0.018^{* * *}$ & -0.016 & -0.016 & -0.015 & -0.017 & -0.016 & -0.015 \\
\hline & $\operatorname{Exp}(B)$ & 0.984 & 0.983 & 0.984 & 0.984 & 0.985 & 0.984 & 0.985 & 0.985 \\
\hline & Wald & (10.538) & $(11.892)$ & $(10.545)$ & $(10.539)$ & $(9.223)$ & $(10.181)$ & $(9.241)$ & (9.206) \\
\hline & VIF & 1.210 & 1.262 & 1.210 & 1.210 & 1.217 & 1.273 & 1.217 & 1.217 \\
\hline \multirow{4}{*}{ Certification } & B & 0.062 & 0.066 & 0.061 & 0.062 & 0.099 & 0.101 & 0.098 & 0.100 \\
\hline & $\operatorname{Exp}(B)$ & 1.064 & 1.068 & 1.063 & 1.064 & 1.104 & 1.106 & 1.102 & 1.105 \\
\hline & Wald & $(0.317)$ & $(0.358)$ & $(0.312)$ & $(0.319)$ & $(0.769)$ & $(0.803)$ & $(0.749)$ & $(0.782)$ \\
\hline & VIF & 1.127 & 1.128 & 1.127 & 1.130 & 1.199 & 1.199 & 1.200 & 1.203 \\
\hline \multirow{4}{*}{$\begin{array}{l}\text { Purchases } \\
\text { on Account }\end{array}$} & B & $-0.866^{* * *}$ & $-0.862^{* * *}$ & -0.844 & -0.866 & -0.829 & -0.826 & -0.774 & -0.828 \\
\hline & $\operatorname{Exp}(B)$ & 0.421 & 0.422 & 0.430 & 0.421 & 0.436 & 0.438 & 0.461 & 0.437 \\
\hline & Wald & (25.873) & (25.656) & (10.383) & (25.830) & (23.507) & (23.379) & (8.693) & (23.403) \\
\hline & VIF & 1.292 & 1.292 & 3.168 & 1.294 & 1.305 & 1.305 & 3.202 & 1.307 \\
\hline \multirow{4}{*}{ Industry } & B & $0.257^{* *}$ & $0.259 * *$ & 0.278 & 0.261 & 0.315 & 0.315 & 0.368 & 0.327 \\
\hline & $\operatorname{Exp}(B)$ & 1.294 & 1.296 & 1.321 & 1.299 & 1.371 & 1.370 & 1.445 & 1.387 \\
\hline & Wald & (5.433) & $(5.521)$ & $(1.652)$ & $(4.154)$ & $(7.768)$ & (7.770) & $(2.802)$ & (6.238) \\
\hline & VIF & 1.102 & 1.103 & 3.818 & 1.402 & 1.148 & 1.148 & 3.927 & 1.462 \\
\hline
\end{tabular}


Table 5: Continuation

\begin{tabular}{|c|c|c|c|c|c|c|c|c|c|}
\hline \multirow{4}{*}{ Loan size } & B & $0.0003^{* * *}$ & $0.0003^{* * *}$ & 0.0003 & 0.0003 & 0.0003 & 0.0003 & 0.0003 & 0.0004 \\
\hline & $\operatorname{Exp}(B)$ & 1.000 & 1.000 & 1.000 & 1.000 & 1.000 & 1.000 & 1.000 & 1.000 \\
\hline & Wald & $(10.464)$ & $(10.325)$ & (10.469) & $(4.300)$ & (10.787) & (10.670) & (10.807) & $(4.801)$ \\
\hline & VIF & 1.184 & 1.184 & 1.186 & 2.829 & 1.238 & 1.238 & 1.239 & 2.889 \\
\hline \multirow{4}{*}{$\begin{array}{l}\text { Firm Age } \times \\
\text { Experience }\end{array}$} & B & - & 0.0003 & - & - & - & 0.0002 & - & - \\
\hline & $\operatorname{Exp}(B)$ & - & 1.000 & - & - & - & 1.000 & - & - \\
\hline & Wald & - & $(1.021)$ & - & - & - & $(0.623)$ & - & - \\
\hline & VIF & - & 4.375 & - & - & - & 4.406 & - & - \\
\hline \multirow{4}{*}{$\begin{array}{l}\text { Purchases } \\
\text { on Account } \\
\times \text { Industry }\end{array}$} & B & - & - & -0.035 & - & - & - & -0.088 & - \\
\hline & $\operatorname{Exp}(B)$ & - & - & 0.965 & - & - & - & 0.916 & - \\
\hline & Wald & - & - & $(0.012)$ & - & - & - & $(0.076)$ & - \\
\hline & VIF & - & - & 6.035 & - & - & - & 6.082 & - \\
\hline \multirow{4}{*}{$\begin{array}{l}\text { Industry } \\
\times \text { Loan Size }\end{array}$} & B & - & - & - & -0.00001 & - & - & - & -0.00003 \\
\hline & $\operatorname{Exp}(B)$ & - & - & - & 1.000 & - & - & - & 1.000 \\
\hline & Wald & - & - & - & $(0.003)$ & - & - & - & $(0.030)$ \\
\hline & VIF & - & - & - & 2.964 & - & - & - & 2.974 \\
\hline \multirow{4}{*}{$\begin{array}{l}\text { Borrower- } \\
\text { Bank } \\
\text { Proximity }\end{array}$} & B & - & - & - & - & 0.016 & 0.016 & 0.017 & 0.017 \\
\hline & $\operatorname{Exp}(B)$ & - & - & - & - & 1.017 & 1.016 & 1.017 & 1.017 \\
\hline & Wald & - & - & - & - & (7.133) & $(6.608)$ & $(7.222)$ & $(7.212)$ \\
\hline & VIF & - & - & - & - & 1.200 & 1.209 & 1.206 & 1.204 \\
\hline \multirow{4}{*}{$\begin{array}{l}\text { Financial } \\
\text { Development }\end{array}$} & B & - & - & - & - & 0.010 & 0.007 & 0.013 & 0.010 \\
\hline & $\operatorname{Exp}(B)$ & - & - & - & - & 1.010 & 1.007 & 1.013 & 1.010 \\
\hline & Wald & - & - & - & - & $(0.003)$ & $(0.001)$ & $(0.005)$ & $(0.003)$ \\
\hline & VIF & - & - & - & - & 1.248 & 1.248 & 1.254 & 1.249 \\
\hline $\begin{array}{l}\text { Country } \\
\text { dummies }\end{array}$ & & Yes & Yes & Yes & Yes & No & No & No & No \\
\hline Year dummies & & Yes & Yes & Yes & Yes & Yes & Yes & Yes & Yes \\
\hline $\mathbf{N}$ & & 1,881 & 1,881 & 1,881 & 1,881 & 1,881 & 1,881 & 1,881 & 1,881 \\
\hline
\end{tabular}

\section{Goodness of Fit Measures}

\begin{tabular}{l|c|c|c|c|c|c|c|c|c}
\hline McFadden $\boldsymbol{R}^{2}$ & & 0.041 & 0.041 & 0.041 & 0.041 & 0.043 & 0.043 & 0.044 & 0.043 \\
\hline $\begin{array}{l}\mathbf{- 2} \text { Log- } \\
\text { Likelihood }\end{array}$ & $2,378.498$ & $2,377.308$ & $2,378.484$ & $2,378.492$ & $2,371.794$ & $2,371.794$ & $2,371.036$ & $2,371.716$ \\
\hline
\end{tabular}

Note: Table 5 reports logistic regression results for the pooled sample. The dependent variable Collateral takes the value 1 (the firm has provided collateral for its most recent line of credit) or 0 (otherwise). Firm Age represents the number of years the firm has been operating. Firm Size indicates the number of full-time employees. Growth Rate is the percentage change in the number of employees in the last three years. Ownership Concentration represents the percentage of the firm held by the largest owner. Credit Sales indicates the percentage of credit sales to total sales. Experience is defined as the number of years of experience of the top manager in the industry. The dummy variable Certification takes the value 1 (the firm has an internationally recognized quality certification) or 0 (otherwise). The reference group is the firms that do not have a certification. Purchases on Account indicates the percentage of the value of total annual purchases of material inputs or services paid after delivery. The dummy variable Industry takes the value 1 (the firm is in the manufacturing industry) or 0 (the firm is in the service industry). The reference group is the firms that are in the service industry. Loan Size is the total value of the loan in thousands of dollars. Borrower-Bank Proximity indicates the number of branches of commercial banks per 100,000 adults. Financial Development is the ratio of the volume of credit to private sector to GDP. The first four columns present the results of models with country dummies. The second four columns present the results of models where we use country-level variables (Borrower-Bank Proximity and Financial Development) instead of country dummies. The Wald statistics are in parentheses. Statistical significance at the $1 \%, 5 \%$, and $10 \%$ levels is denoted by ${ }^{* *},{ }^{* *}$, and ${ }^{*}$, respectively.

Source: Own calculations 
The statistically significant $(p<0.01)$ negative coefficient of Experience shows that the higher the experience of the top manager in the industry, the lower the probability that the SME provides collateral. This finding provides support for $\mathrm{H} 6$ and is consistent with the argument of Leeth and Scott (1989) that banks think that the probability of loan non-payment decreases with the experience of the top manager. The result is also consistent with that of Duarte et al. (2017). The negative coefficient of Purchases on Account, which is also statistically significant $(p<0.01)$, shows that the higher the percentage of the material inputs and services purchased on account, the lower the probability that the loan is secured. This finding provides support for H8. The result is consistent with the argument that when suppliers extend trade credit to a firm, they provide a reassuring signal to the banks about the quality of the firm as a borrower (Gama and Van Auken, 2015). It also corresponds to the finding of Duarte et al. (2017).

The statistically significant $(p<0.05)$ positive coefficient of the dummy variable Industry shows that firms in the manufacturing industry have a higher probability of providing collateral for bank loans than service industry firms. We reject $\mathrm{H} 9$ with this result. The finding signals that manufacturing industry firms are considered to be risky by banks because they have higher borrowing needs and face difficulties in presenting their technical development plans. H10 posits that loan size is related to the likelihood of pledging collateral for loans. The statistically significant $(p<0.01)$ positive coefficient of Loan Size suggests that SMEs that receive a larger bank loan have a higher probability of pledging collateral. This result provides support for the argument that non-payment risk increases with loan size (Menkhoff et al., 2012). It is also in line with that of Hanedar et al. (2014b).

We see that the odds of the procurement of collateral do not have a statistically significant relationship with Firm Size, Credit Sales, Firm Growth, Ownership Concentration and Certification. These findings do not support H2, H3, H4, H5 and H8. The results for firm size and firm growth rate signal that smaller firms and high growth firms do not have higher credit risk, contrary to the arguments of several studies in the literature (e.g., Brown and Lee, 2019; Freel et al., 2012; Knyazeva and Knyazeva, 2012; Steijvers et al., 2010).

The second column gives the results of Model 2, where the interaction effect of Firm Age and Experience is added. We add this interaction effect because we presume that an increase in the number of years of experience of the top manager in the industry strengthens the negative effect of firm age on collateral use. Moreover, we also expect to find that higher firm age will enhance the negative effect of manager experience on the use of collateral. However, we find that the interaction effect has a statistically insignificant coefficient. The third column gives the results of Model 3, where 
the interaction effect of Experience and Purchases on Account is added. We add this interaction effect to the model because we expect that an increase in the percentage of the value of total annual purchases of material inputs or services enhances the negative relationship of the number of years of experience of the top manager in the industry with the probability of pledging collateral. Moreover, we presume that an increase in the number of years of experience of the top manager strengthens the negative relationship between the percentage of the value of total annual purchases of material inputs or services and collateral use. We find that the interaction effect of Experience and Purchases on Account has a statistically insignificant coefficient.

The fourth column gives the results of Model 4, where the interaction effect of Manufacturing and Loan Size is added. Namely, we presume that large loan size strengthens the positive effect of operating in the manufacturing industry on collateral use. Moreover, we also expect to find that operating in the manufacturing industry rather than the service industry will increase the positive effect of loan size on the use of collateral. We find that the interaction effect of Manufacturing and Loan Size is not statistically significant.

The second four columns show the results of logistic regressions where we use country-level variables instead of country dummies. Using country-level variables can be viewed as a robustness check for models that use only country dummies. The fifth column shows the results of Model 5, where we do not include any interaction effects. We observe that the findings for firm-specific variables are similar for Model 1 and Model 5. We also find that Borrower-Bank Proximity has a statistically significant $(p<0.01)$ positive coefficient. The positive coefficient shows that there is a positive relationship between the number of branches of commercial banks per 100,000 adults and the likelihood that the loan is secured. The finding signals that banking sector growth in emerging economies that results in an increase in the number of bank branches also leads banks to improve their credit risk management practices. The result contradicts the argument of Hainz et al. (2013) and is not in line with the finding of Duarte et al. (2017). In Model 5, we also see that Financial Development does not have a statistically significant coefficient.

The sixth, seventh, and eighth columns show the results of Models 6, 7 and 8, where we include the interaction effects of Firm Age and Experience, Experience and Purchases on Account, and Industry and Loan Size respectively. We observe that the findings are similar to those of the models that use country dummies instead of country-level variables.

As a robustness check, we also use the percentage of change in annual sales in the last three years as a proxy for firm growth rate. Our results remain similar after this change. 


\section{Conclusion}

This paper is one of the scarce studies to examine empirically the determinants of collateralized borrowing in the context of emerging markets. In this study, we analyse the determinants of the procurement of collateral for bank loans using survey data from the WBES for nine emerging market economies. Our cross-country sample is made up of 1,881 SMEs that had secured a bank loan. The findings show that older firms have a lower probability of providing collateral for bank financing. Moreover, the years of experience of the top manager in the industry have a negative effect on the probability that a loan is secured. Loans received by firms with a higher percentage of material inputs and services purchased on account are less likely to be secured. We also find that SMEs that operate in the manufacturing industry are more likely to provide collateral for bank loans than service industry firms. Furthermore, the results show that loan size has a positive effect on the presence of collateral. The results also show that SMEs that operate in countries with higher borrower-bank proximity have a higher probability of collateral use.

The findings of this paper have important implications for access of SMEs to bank financing without providing collateral. Young firms should work towards lowering the information asymmetry by improving the quality of their financial reporting. Moreover, SMEs can signal their borrower quality with a high proportion of material inputs and services paid on account. Hiring top managers who have long-term experience in the industry also has a positive effect on perceived borrower quality. Applying for smaller loans can be an option for emerging market SMEs that do not want to provide collateral.

As any research, this study has certain limitations. One limitation of the study is that it uses data from only nine of the emerging markets. Moreover, since we do not have access to the financial data of the SMEs in the sample, the effect of liquidity status and financial performance on the probability of pledging collateral for bank loans cannot be analysed. WBES data do not contain information on the interest rates of the bank loans and loan maturity; therefore, we could not analyse either whether interest rates paid on the loans and loan maturity have an impact on collateral use. Additionally, we should note that pooled sample results may not represent the logistic regression estimation results of unpooled country samples.

Future studies can extend our findings by enlarging the sample so that it includes SMEs that operate also in other emerging markets. Moreover, future research can replicate this study by using banks' credit data that include firms' financial data and analyse which financial variables affect the probability of pledging collateral. Since the banks' internal data also include information on loan interest rates and maturity, the effect of interest rates paid on the loans and loan maturity on collateral use can be examined. Analysing the determinants of the ratio of collateral value to the size of the loan is another recommendation for future. 


\section{References}

Beck, T., Demirguc-Kunt, A., Laeven, L., et. al. (2006). The Determinants of Financing Obstacles. Journal of International Money and Finance, 25(6), 932-952, https://doi.org/10.1016/j.jimonfin.2006.07.005

Beck, T., Demirguc-Kunt, A., Maksimovic, V. (2008). Financing Patterns around the World: Are Small Firms Different? Journal of Financial Economics, 89, 467-487, https://doi.org/10.1016/j.jfineco.2007.10.005

Berger, A. N., Udell, G. F. (1990). Collateral, Loan Quality, and Bank Risk. Journal of Monetary Economics, 25(1), 21-42, https://doi.org/10.1016/0304-3932(90)90042-3

Berger, A. N., Udell, G. F. (1995). Relationship Lending and Lines of Credit in Small Firm Finance. Journal of Business, 68(3), 351-381, https://doi.org/10.1086/296668

Berger, A. N., Udell, G. F. (2002). Small Business Credit Availability and Relationship Lending: The Importance of Bank Organizational Structure. The Economic Journal, 112(477), F32-F53, https://doi.org/10.1111/1468-0297.00682

Berger, A. N., Udell, G. F. (2006). A More Complete Conceptual Framework for SME Finance. Journal of Banking and Finance, 30(11), 2945-2966, https://doi:10.1016/j. jbankfin.2006.05.008

Bernanke, B. S. (2011). Lessons from Emerging Market Economies on the Sources of Sustained Growth. Speech at the Cleveland Clinic "Ideas for Tomorrow" Series. Available at: https://www.federalreserve. gov/newsevents/speech/bernanke20110928a.htm

Bester, H. (1985). Screening vs. Rationing in Credit Markets with Imperfect Information. American Economic Review, 75(4), 850-855.

Binks, M. R., Ennew, C. T. (1996). Growing Firms and the Credit Constraint. Small Business Economics, 8(1), 17-25. https://doi.org/10.1007/bf00391972

Boot, A. W. A., Thakor, A. V., Udell, G. F. (1991). Secured Lending and Default Risk: Equilibrium Analysis, Policy Implications and Empirical Results. Economic Journal, 101(406), 458-472, https://doi.org/10.2307/2233552

Brealey, R., Myers, S., Allen, F. (2020). Principles of Corporate Finance. $13^{\text {th }}$ edition. New York, N.Y.: McGraw-Hill. ISBN 978-12-600-1390-0.

Brigham, E. F., Ehrhardt, M. C. (2020). Financial Management: Theory and Practice. $16^{\text {th }}$ edition. Boston, M.A.: Cengage. ISBN 978-13-379-0260-1.

Brown, R., Lee, N. (2019). Strapped for Cash? Funding for UK High Growth SMEs since the Global Financial Crisis. Journal of Business Research, 99, 37-45, https://doi. org/10.1016/j.jbusres.2019.02.001

Carbo-Valverde, S., Rodriguez-Fernandez, F., Udell, G. F. (2016). Trade Credit, the Financial Crisis, and Firm Access to Finance. Journal of Money, Credit and Banking, 48(1), 113-143, https://doi.org/10.1111/jmcb.12292 
Chakraborty, A., Hu, C. X. (2006). Lending Relationships in Line-of-Credit and Nonlineof-Credit Loans: Evidence from Collateral Use in Small Business. Journal of Financial Intermediation, 15(1), 86-107, https://doi.org/10.1016/j.jfi.2005.07.002

Christopoulos, A. G., Dokas, I. G., Kalantonis, P., et al. (2018). Investigation of Financial Distress with a Dynamic Logit Based on the Linkage Between Liquidity and Profitability Status of Listed Firms. Journal of the Operational Research Society, 70(10), 1817-1829, https://doi.org/10.1080/01605682.2018.1460017

Chung, C. Y., Kim, H., Ryu, D. (2017). Foreign Investor Trading and Information Asymmetry: Evidence from a Leading Emerging Market. Applied Economics Letters, 24(8), 540-544, https://doi.org/10.1080/13504851.2016.1208349

Cowling, M. (2010). The Role of Loan Guarantee Schemes in Alleviating Credit Rationing in the UK. Journal of Financial Stability, 6(1), 36-44, https://doi:10.1016/j.jfs.2009.05.007

Duarte, F. D., Gama, A. P. M., Esperanca, J. P. (2017). Collateral-Based in SME Lending: The Role of Business Collateral and Personal Collateral in Less-Developed Countries. Research in International Business and Finance, 39, 406-422, https://doi.org/10.1016/j. ribaf.2016.07.005

Dvouletý, O. (2017). Effects of Soft Loans and Credit Guarantees on Performance of Supported Firms: Evidence from the Czech Public Programme START. Sustainability, 9(12), 1-17, https://doi.org/10.3390/su9122293

Dvouletý, O., Čadil, J., Mirošník, K. (2019). Do Firms Supported by Credit Guarantee Schemes Report Better Financial Results 2 Years After the End of Intervention? The B.E. Journal of Economic Analysis \& Policy, 19(1), 1-20, https://doi.org/10.1515/bejeap-2018-0057

Freel, M., Carter, S., Tagg, S., et al. (2012). The Latent Demand for Bank Debt: Characterizing "Discouraged Borrowers". Small Business Economics, 38(4), 399-418, https://doi.org/10.1007/s11187-010-9283-6

Gama, A. P. M., Van Auken, H. (2015). The Interdependence between Trade Credit and Bank Lending: Commitment in Intermediary Firm Relationships. Journal of Small Business Management, 53(4), 886-904, https://doi.org/10.1111/jsbm.12115

Godlewski, C. J., Weill, L. (2011). Does Collateral Help Mitigate Adverse Selection? A CrossCountry Analysis. Journal of Financial Services Research, 40(1-2), 49-78, https://doi.org/10.1007/s10693-010-0099-y

Gompers, P. (1995). Optimal Investment, Monitoring, and the Staging of Venture Capital. Journal of Finance, 50(5), 1461-1489, https://doi.org/10.1111/j.1540-6261.1995. tb05185.x

Hainz, C., Weill, L., Godlewski, C. J. (2013). Bank Competition and Collateral: Theory and Evidence. Journal of Financial Services Research, 44(2), 131-148, https://doi.org/10.1007/ s10693-012-0141-3

Hair, J. F., Babin, B. J., Anderson, R. E., et al. (2018). Multivariate Data Analysis. $8^{\text {th }}$ edition. Hampshire: Cengage. ISBN 978-14-737-5654-0. 
Hanedar, E. Y., Broccardo, E., Bazzana, F. (2014a). Collateral Requirements of SMEs:

The Evidence from Less-Developed Countries. Journal of Banking and Finance, 38, 106-121, https://doi.org/10.1016/j.jbankfin.2013.09.019

Hanedar, E. Y., Broccardo, E., Bazzana, F. (2014b). Collateral in Emerging Economies, in Arouri, M. E. H., Boubaker, S., Nguyen, D. K., eds., Emerging Markets and the Global Economy: A Handbook. Cambridge, Massachusetts: Academic Press, pp. 383-411, https://doi.org/10.1016/b978-0-12-411549-1.00017-x

Harhoff, D., Körting, T. (1998). Lending Relationships in Germany - Empirical Evidence from Survey Data. Journal of Banking and Finance, 22(10-11), 1317-1353, https://doi.org/10.1016/s0378-4266(98)00061-2

Huidrom, R., Kose, M. A., Ohnsorge, F. L. (2017). How Important are Spillovers from Major Emerging Markets? World Bank. Washington, D.C., Policy Research Working Paper No. 8093., https://doi.org/10.1596/1813-9450-8093

IFC (2017). MSME Finance Gap: Assessment of the Shortfalls and Opportunities in Financing Micro, Small and Medium Enterprises in Emerging Markets. Washington, D.C.: World Bank, https://doi.org/10.1596/28881

Jimenez, G., Salas, V., Saurina, J. (2006). Determinants of Collateral. Journal of Financial Economics, 81(2), 255-281, https://doi.org/10.1016/j.jfineco.2005.06.003

Knyazeva, A., Knyazeva, D. (2012). Does Being Your Bank's Neighbour Matter? Journal of Banking and Finance, 36(4), 1194-1209, https://doi.org/10.1016/j.jbankfin.2011.11.011

Leeth, J. D., Scott, J. A. (1989). The Incidence of Secured Debt: Evidence from the Small Business Community. The Journal of Financial and Quantitative Analysis, 24(3), 379-394, https://doi.org/10.2307/2330818

Menkhoff, L., Neuberger, D., Rungruxsirivorn, O. (2012). Collateral and its Substitutes in Emerging Markets' Lending. Journal of Banking and Finance, 36(3), 817-834, https://doi.org/10.1016/j.jbankfin.2011.09.010

Menkhoff, L., Neuberger, D., Suwanaporn, C. (2006). Collateral-Based Lending in Emerging Markets: Evidence from Thailand. Journal of Banking and Finance, 30(1), 1-21, https://doi.org/10.1016/j.jbankfin.2004.12.004

Minard, P. (2016). Signalling through the Noise: Private Certification, Information Asymmetry and Chinese SMEs' Access to Finance. Journal of Asian Public Policy, 9(3), 243-256, https://doi.org/10.1080/17516234.2015.1083412

OECD (2006). The SME Financing Gap: Theory and Evidence. Financial Market Trends, 2006(2), pp. 87-97. https://doi.org/10.1787/fmt-v2006-art11-en

Rahman, A., Belas, J., Kliestik, T., et al. (2017). Collateral Requirements for SME Loans: Empirical Evidence from the Visegrad Countries. Journal of Business, Economics and Management, 18(4), 650-675, https://doi.org/10.3846/16111699.2017.1357050

Rocha, R. R., Arvai, Z., Farazi, S. (2011). Financial Access and Stability. A Road Map for the Middle East and North Africa. Washington, D.C.: The World Bank. ISBN 978-0-8213-8835-8. 
Scott, J. A. (2006). Loan Officer Turnover and Credit Availability for Small

Firms. Journal of Small Business Management, 44(4), 544-566, https://doi. org/10.1111/j.1540-627X.2006.00186.x

Steijvers, T., Voordeckers, W., Vanhoof, K. (2010). Collateral, Relationship Lending and Family Firms. Small Business Economics, 34(3), 243-259, https://doi.org/10.1007/ s11187-008-9124-z

Wasiuzzaman, S., Nurdin, N., Abdullah, A. H., et al. (2019). Creditworthiness and Access to Finance: A Study of SMEs in the Malaysian Manufacturing Industry. Management Research Review, 43(3), 293-310, https://doi.org/10.1108/MRR-05-2019-0221

World Bank (2018). Small and Medium Enterprises (SMEs) Finance. Retrieved from: http://www.worldbank.org/en/topic/smefinance

Zecchini, S., Ventura, M. (2009). The Impact of Public Guarantees on Credit to SMEs. Small Business Economics, 32(2), 191-206, https://doi.org/10.1007/s11187-007-9077-7

Zikovic, I. T. (2018). Challenges in Predicting Financial Distress in Emerging Economies: The Case of Croatia. Eastern European Economics, 56(1), 1-27, https://doi.org/10.1080/00128775. 2017.1387059 